\title{
Surgical management of giant retroperitoneal lymphangioma in a child
}

\author{
Naveen Kumar, ${ }^{1}$ Priyank Yadav ${ }_{1}^{1}$ Mohammad S Ansari, ${ }^{1}$ Hira Lal ${ }^{2}$
}

${ }^{1}$ Urology and Renal transplant, Sanjay Gandhi Postgraduate Institute of Medical Sciences, Lucknow, Uttar Pradesh, India ${ }^{2}$ Radiodiagnosis, Sanjay Gandhi Postgraduate Institute of Medical Sciences, Lucknow, Uttar Pradesh, India

Correspondence to Dr Hira Lal; hiralal2007@yahoo.co.in

Accepted 4 February 2020

Check for updates

(C) BMJ Publishing Group Limited 2020. No commercial re-use. See rights and permissions. Published by BMJ.

To cite: Kumar N, Yadav $P$, Ansari MS, et al. BMJ Case Rep 2020;13:e234447. doi:10.1136/bcr-2020 234447

\section{DESCRIPTION}

A 3-year-old boy was noticed by parents to have right flank distension. On evaluation with ultrasonography, there was a large multiseptate collection with internal echoes occupying the right half of retroperitoneum. CT of the abdomen revealed a $10 \times 12 \times 13 \mathrm{~cm}$ well-defined, thin-walled multiloculated cystic lesion with enhancing septae displacing the right kidney and extending from the under surface of the liver above to the pelvic brim below (figure 1). The boy underwent laparotomy and intraoperatively a $12 \times 12 \times 10 \mathrm{~cm}$ globular cystic mass was found, arising from the retroperitoneum on the right side displacing the bowel and right kidney and ureter medially and having extension into the posterior abdominal wall and paravertebral muscles (figure 2). The cystic mass was completely excised and its histopathological examination revealed a fibrocollagenous cyst wall along with flattened epithelium at places with moderate-todense lymphoplasmacytic inflammatory infiltrate and areas of haemorrhage. The cystic cavity was filled with a proteinaceous and haemorrhagic material. These features were suggestive of a lymphangioma. After surgery, the child had an uneventful recovery and at 18 months of follow-up, there is no abdominal distension on clinical examination and no recurrent lesion on ultrasonography.

A lymphangioma is a benign proliferation of lymphatic tissue believed to develop from the early sequestration of lymphatic channels that fail to establish connections with normal draining lymphatics. Retroperitoneal lymphatic malformations are extremely rare and comprise less than $1 \%$ of the abdominal lymphatic malformations. ${ }^{1}$ Three histological types of lymphangiomas are described: cystic, capillary and cavernous. ${ }^{2}$ Retroperitoneal lymphangioma is commonly of cystic type. ${ }^{3}$ Most cystic lymphangiomas in the body are present in the first 2 years of life, however lymphangiomas of the retroperitoneum are usually diagnosed in older children or adults. ${ }^{3}$ It can present as a soft, slowly growing and painless mass or it may be detected incidentally during the evaluation of an unrelated complaint.

Ultrasound is a sensitive and often the initial tool for evaluation of cystic abdominal masses, particularly for identifying septations and floating debris. ${ }^{3}$ On CT, cystic lymphangiomas are well-defined, homogeneous, usually multicystic and may have mild enhancement of the septa or the wall after intravenous contrast administration. ${ }^{3}$ They may not be limited to a particular abdominal compartment and may displace intra-abdominal organs and

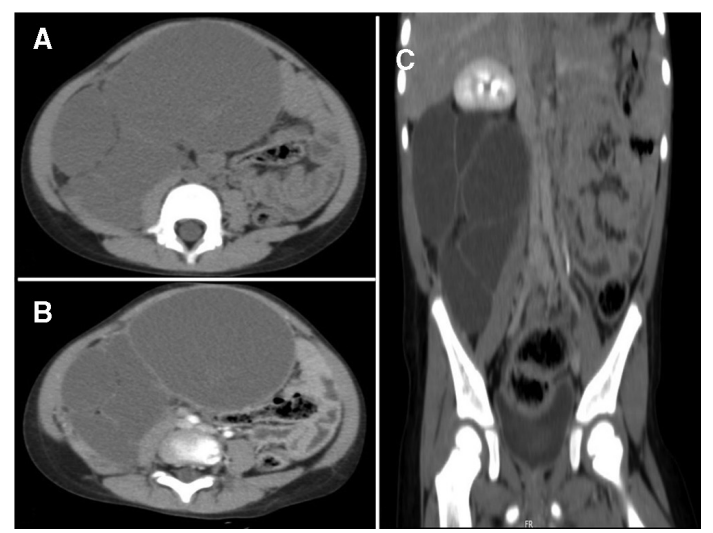

Figure 1 CT abdomen in (A) non-contrast axial, (B) contrast-enhanced axial and (C) coronal planes showing retroperitoneal multiloculated cystic lesion.

vessels. An important feature on imaging that differentiates these lesions from other pathologies is the insinuating nature crossing multiple compartments, as was in this case. They may also form unilocular or multilocular cystic masses and can encroach on vital structures. Pancreatic pseudocyst and retroperitoneal cystic teratoma must be kept in mind as a differential diagnosis. ${ }^{4}$

However, the final diagnosis is made on pathological examination which shows large macroscopic or microscopic cysts without any capsule and lined by endothelial cells. The cysts are filled with

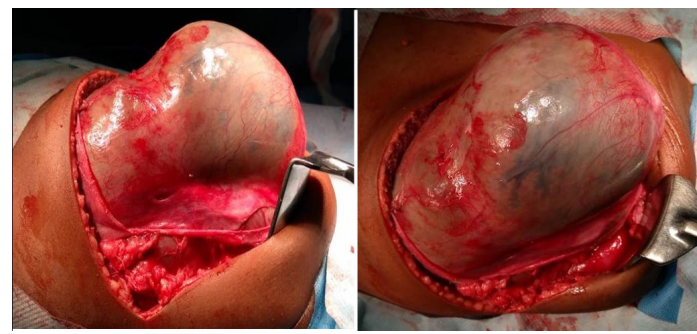

Figure 2 Intraoperative photograph shows globular cystic retroperitoneal mass.

\section{Patient's perspective}

Patient's father: I was told by my doctor that my son has a fluid-filled swelling in his belly which did not look like cancer but required removal by surgery. The surgery went on well I was happy to know that the tissue report did not show any cancer. Presently, my son is doing well and I am very happy that his case was managed very well. 


\section{Learning points}

- Giant retroperitoneal cystic lymphangioma is rare in young children and it usually presents with abdominal distension without any other symptoms.

- Complete resection is the only curative treatment.

- The diagnosis is confirmed by histopathological examination of resected specimen.

chylous, serous, haemorrhagic or mixed fluid. The connective tissue is composed of collagen with and without lymphocytes.

Complete resection as the treatment of choice is recommended in all cases including asymptomatic cases due to risk of future complications like haemorrhage, infection, malignant transformation or compression of vital structures. ${ }^{5}$ Conservative methods, including aspiration, cyst enterostomy and peritoneal marsupialisation, are now rarely considered due to the high rate of recurrence. ${ }^{6}$ Surgically unresectable lesions can be treated with intracystic injection of a sclerosing agent, preferably OK-432.

Twitter Naveen Kumar @babu_drjmt
Contributors $\mathrm{HL}$ conceived the manuscript and provided the $\mathrm{CT}$ images. NK and PY prepared the manuscript. Consent was taken by NK. MSA reviewed the manuscript. MSA performed the surgery and was assisted by NK and PY. The final draft was read and approved by all authors.

Funding The authors have not declared a specific grant for this research from any funding agency in the public, commercial or not-for-profit sectors.

Competing interests None declared.

Patient consent for publication Parental/guardian consent obtained.

Provenance and peer review Not commissioned; externally peer reviewed.

\section{REFERENCES}

1 Davidson AJ, Hartman DS. Lymphangioma of the retroperitoneum: CT and sonographic characteristic. Radiology 1990;175:507-10.

2 Schneider G, Seidel R, Altmeyer K, et al. Lymphangioma of the pancreas and the duodenal wall: MR imaging findings. Eur Radiol 2001;11:2232-5.

3 Wilson SR, Bohrer S, Losada R, et al. Retroperitoneal lymphangioma: an unusual location and presentation. J Pediatr Surg 2006;41:603-5.

4 DI Marco M, Grassi E, Vecchiarelli S, et al. Retroperitoneal lymphangioma: a report of 2 cases and a review of the literature regarding the differential diagnoses of retroperitoneal cystic masses. Oncol Lett 2016;11:3161-6.

5 Hancock BJ, St-Vil D, Luks Fl, et al. Complications of lymphangiomas in children. J Pediatr Surg 1992;27:220-6.

6 Surlin V, Georgescu E, Dumitrescu C, et al. Retropancreatic cystic lymphangioma considerations upon a case. Rom J Morphol Embryol 2011;52:493-6.

7 Ogita S, Tsuto T, Deguchi E, et al. Ok-432 therapy for unresectable lymphangiomas in children. J Pediatr Surg 1991;26:263-70.

Copyright 2020 BMJ Publishing Group. All rights reserved. For permission to reuse any of this content visit

https://www.bmj.com/company/products-services/rights-and-licensing/permissions/

BMJ Case Report Fellows may re-use this article for personal use and teaching without any further permission.

Become a Fellow of BMJ Case Reports today and you can:

- Submit as many cases as you like

- Enjoy fast sympathetic peer review and rapid publication of accepted articles

- Access all the published articles

- Re-use any of the published material for personal use and teaching without further permission

Customer Service

If you have any further queries about your subscription, please contact our customer services team on +44 (0) 2071111105 or via email at support@bmj.com.

Visit casereports.bmj.com for more articles like this and to become a Fellow 